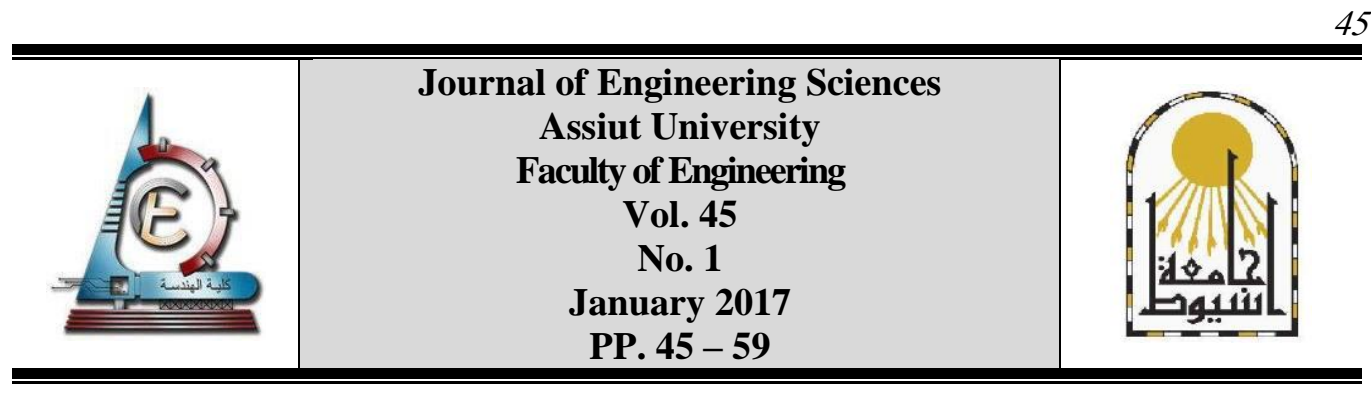

\title{
PROPERTIES OF AL/CU BIMETALLIC PLATE PREPARED BY P/M TECHNIQUE: SINTERING TEMPERATURE EFFECT
}

\author{
Moataz H. Ata \\ Department of Mechanical Engineering, Faculty of Industrial Education, Sohag University, \\ 82524 Sohag, Egypt. Email address: moatzata@yahoo.com
}

Received 7 November 2016; Accepted 21 December 2016

\begin{abstract}
The goal of this work was to fabricate an aluminum/copper powder metallurgy bimetal plates at various sintering temperature ranging between $300^{\circ} \mathrm{C}$ and $600^{\circ} \mathrm{C}$. Microstructure and properties for sintering specimens were performed to appreciate the effect of sintering temperature on the final $\mathrm{Al} / \mathrm{Cu}$ bimetal properties. Three intermetallic compounds (IMCs) were detected $\left(\mathrm{Al}_{2} \mathrm{Cu}, \mathrm{Al}_{4} \mathrm{Cu}_{9}\right.$ and $\left.\mathrm{AlCu}\right)$ between $\mathrm{Al}$. and $\mathrm{Cu}$. interface. Cracks were obtained for the specimens that were sintered at $600^{\circ} \mathrm{C}$, lead to weaken and separation of the $\mathrm{Al} / \mathrm{Cu}$ plates. The maximum strength for bonding was measured for the specimens that were sintered at $500^{\circ} \mathrm{C}$. For the samples which sintered at $500^{\circ} \mathrm{C}$, the lower electrical resistivity was detected where the good sintering was occurred for this specimen.
\end{abstract}

Keywords: Bimetal plate, powder metallurgy, intermetallic compound, bond strength, volume shrinkage.

\section{Introduction}

$\mathrm{Al} / \mathrm{Cu}$ bimetal plates are used for many electronic and automotive components because of several advantages [1-5]. One material can't supply a large spectrum of physical, chemical and mechanical properties so, the indigence for dissimilar material joints increases [6]. The Al. and $\mathrm{Cu}$ assembly gives several properties as high thermal conductivity and low electrical resistivity of the copper and the low density of the aluminum [7]. $\mathrm{Cu} / \mathrm{Al}$ joints are major in the electronic components fabrication and solar collectors since it can minify materials costs and weight while prolonging the service life [8-11]. $\mathrm{Cu}-\mathrm{Al}$ bimetals was fabricated by repeated hydrostatic extrusion and equal channel angular pressing (ECAP) techniques $\quad[12,13]$, but the $\mathrm{Cu}-\mathrm{Al}$ bimetals result from these techniques have low mechanical strength. Last decades, many works were focused on welding copper to aluminum [14, 15]. However, the welding of copper to aluminum is mostly difficult. The causative factor of the problem is the large difference in their mechanical, physical and chemical properties, and the growth of new Al-Cu compounds at high temperatures, which decrease the $\mathrm{Al}-\mathrm{Cu}$ bimetal properties [16]. From the $\mathrm{Al}-\mathrm{Cu}$ binary phase diagram as shown in Fig. 1 [17], several compounds can be found during high temperature diffusion bonding between $\mathrm{Cu}$. and $\mathrm{Al}$. These compounds such as $\mathrm{Al}_{2} \mathrm{Cu}(\theta), \mathrm{AlCu}$ $\left(\eta_{2}\right), \mathrm{Al}_{3} \mathrm{Cu}_{4}\left(\zeta_{2}\right), \mathrm{Al}_{2} \mathrm{Cu}_{3}(\delta)$ and $\mathrm{Al}_{4} \mathrm{Cu}_{9}\left(\gamma_{2}\right)$ phases could be generated by diffusion bonding between $\mathrm{Al}$ and $\mathrm{Cu}$ at temperature near $773 \mathrm{~K}$ [18, 19]. Recently, Yuan and Weng [20] demonstrated the diffusion stages of the generation energy for each compound and diffusivity. 
Table 1 explains the main properties and characteristics of four selected compounds, which are taken from [21, 22]. Many investigations have focused on the fabricating of a stable $\mathrm{Cu} / \mathrm{Al}$ joint to overcome the difficulties in joining these two dissimilar metals. Abbasi et al. [2] studied the development rate of intermetallic compounds (IMCs) in $\mathrm{Cu}-\mathrm{Al}$ joint fabricated by the cold roll welding technique. Mai and Spowage [3] explained the characteristics of $\mathrm{Cu}-\mathrm{Al}$ joints prepared by laser welding. Lee et al. [4] mentioned the influence of IMCs on the properties of friction-welded $\mathrm{Cu} / \mathrm{Al}$ bimetallic joints. Sahin [5] joined $\mathrm{Al}$ and $\mathrm{Cu}$ by means of friction welding; $\mathrm{CuAl}_{2}, \mathrm{CuAl}$ and $\mathrm{Cu}_{9} \mathrm{Al}_{4} \mathrm{IMCs}_{\mathrm{M}}$ were observed in the $\mathrm{Cu} / \mathrm{Al}$ joint. Cold roll bonding, explosion and friction welding are used for fabricating a strong bond between different combined metals.

However, these techniques are not suitable for $\mathrm{Al} / \mathrm{Cu}$ bimetallic production, because of the growth of IMCs. The conventional joining methods between $\mathrm{Cu}$. and $\mathrm{Al}$. are very difficult. However, several other technologies are subject of current research.

In the current research, $\mathrm{Al} / \mathrm{Cu}$ bimetallic joints were prepared by powder metallurgy (P/M) technique. Production of $\mathrm{Al} / \mathrm{Cu}$ bimetallic joints by $\mathrm{P} / \mathrm{M}$ processing involves rapid solidification that provides some advantages that are significant for the ductility of the material such as decreasing the segregation in the powdered material, producing very fine grains and increasing solid solubility of alloying elements [23, 24]. P/M major advantages are; cost effectiveness in producing certain parts as compared to other manufacturing processes, high production rates, and production of complex shapes [25]. Because all of these advantages $\mathrm{P} / \mathrm{M}$ processes are suitable for fabricating $\mathrm{Al} / \mathrm{Cu}$ bimetallic joints which is the purpose of the current investigations.

In the current study, $\mathrm{Al} / \mathrm{Cu}$ bimetallic plates were fabricated by $\mathrm{P} / \mathrm{M}$ technique at various sintering temperatures and then, the interface microstructures between $\mathrm{Al}$ and $\mathrm{Cu}$ materials were examined by (SEM) with EDX system. The phase constitution in the $\mathrm{Al} / \mathrm{Cu}$ diffusion zone was also analyzed by x-ray diffraction (XRD). The samples porosity was measured by Archimedes laws. The electrical resistance, hardness and mechanical strength were measured for all samples. This research is helpful to progress the microstructure, strength, and electrical conductivity performance of the $\mathrm{Al} / \mathrm{Cu}$.

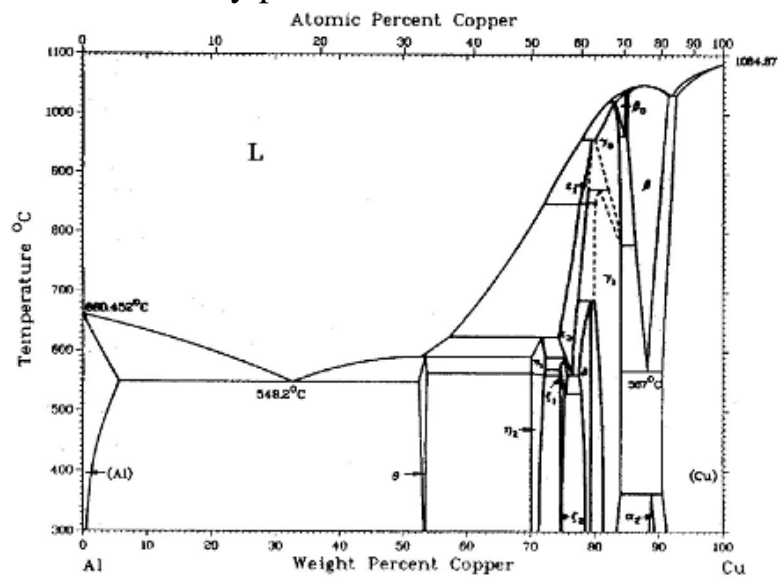

Fig. 1. $\mathrm{Cu} / \mathrm{Al}$ phase diagram [20]. 
Moataz H. Ata, Properties of Al/Cu bimetallic plate prepared by P/M technique: Sintering ...

Table 1.

Selected IMCs in the Al-Cu system [21, 22].

\begin{tabular}{|l|l|l|l|l|}
\hline \multicolumn{1}{|c|}{ Phase } & Composition $(\mathrm{Cu} \%)$ & $\begin{array}{c}\text { Crystal } \\
\text { structure }\end{array}$ & Hardness HV $(5 \mathrm{~g})$ & $\begin{array}{c}\text { Spec. el. } \\
\text { resistance }(\mu \Omega \mathrm{cm})\end{array}$ \\
\hline $\mathrm{Cu}$ & 100 & cubic & $60-100$ & 2 \\
\hline$\gamma_{2}, \mathrm{Al}_{4} \mathrm{Cu}_{9}$ & $62.5-69$ & cubic & 549 & $14.2-17.3$ \\
\hline$\zeta_{2}, \mathrm{Al}_{3} \mathrm{Cu}_{4}$ & $55.2-56.3$ & monoclinic & 616 & 12.2 \\
\hline$\eta_{2}, \mathrm{AlCu}$ & $49.8-52.3$ & monoclinic & 628 & 11.4 \\
\hline$\theta, \mathrm{Al}_{2} \mathrm{Cu}$ & $31.9-33$ & tetragonal & 324 & $7-8$ \\
\hline $\mathrm{Al}$ & 0 & cubic & $20-50$ & 2.4 \\
\hline
\end{tabular}

\section{Experimental procedure}

\subsection{Powder characteristics}

The powders utilized in this work were aluminum powder with $95.3 \%$ purity and copper powder with $98.3 \%$ purity. Both powders were supplied by Sigma-Aldrich. Figure 2 illustrates SEM images of $\mathrm{Cu}$. and Al. powders at magnification of X200. While aluminum powder had irregularly shaped and copper powder had a dendrites shaped. The distributions of $\mathrm{Cu}$. and $\mathrm{Al}$. powders particle size were measured and the obtained results are recorded in Table 2. From this Table it was appeared that the $\mathrm{Cu}$. and the Al. powder are nearly of the equal size. Also, the chemical compositions of these are recorded in Table 3.
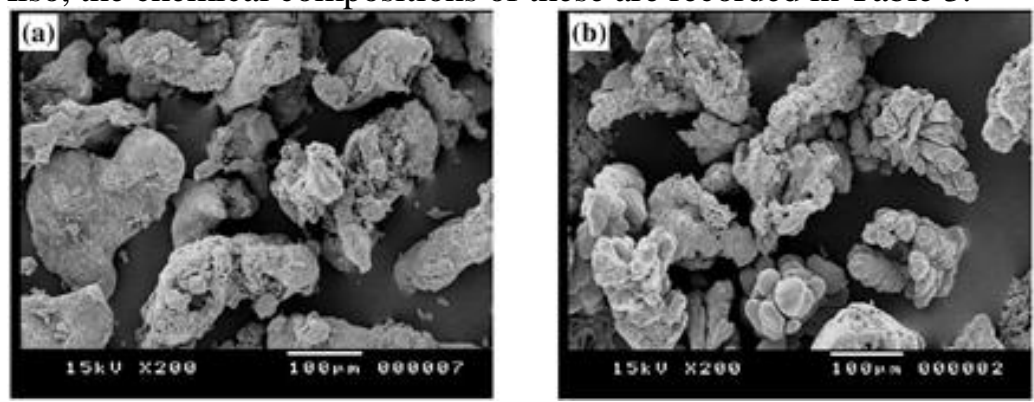

Fig. 2. SEM images of (a) aluminum and (b) copper powders

Table 2.

Particle size distribution \% retained on sieve analysis.

\begin{tabular}{|c|c|c|c|}
\hline \multicolumn{2}{|c|}{ Aluminum powder } & \multicolumn{2}{c|}{ Copper Powder } \\
\hline Grain size $(\mu \mathrm{m})$ & Weight retained \% & Grain size $(\mu \mathrm{m})$ & Weight retained \% \\
\hline$>180$ & 0.12 & $>180$ & 0.815 \\
\hline $125-180$ & 18.8 & $125-180$ & 13.36 \\
\hline $90-125$ & 38.76 & $90-125$ & 29.52 \\
\hline $63-90$ & 27.25 & $63-90$ & 20.66 \\
\hline $45-90$ & 6.2 & $45-90$ & 7.96 \\
\hline Fines & $8.38 \mathrm{max}$ & Fines & $27.3 \mathrm{max}$ \\
\hline
\end{tabular}


Table 3.

Chemical compositions of $\mathrm{Cu}$. and Al. powders.

\begin{tabular}{|c|c|c|c|}
\hline \multicolumn{2}{|c|}{ Composition of Al. powder (wt. \%) } & \multicolumn{2}{c|}{ Composition of Cu. powder (wt. \%) } \\
\hline $\mathrm{Si}$ & 0.05 & $\mathrm{Ag}$ & 0.06 \\
\hline $\mathrm{Cu}$ & 0.12 & $\mathrm{Bi}$ & 0.21 \\
\hline $\mathrm{Fe}$ & 0.13 & $\mathrm{Fe}$ & 0.07 \\
\hline $\mathrm{Mg}$ & 0.27 & $\mathrm{O}_{2}$ & 1.36 \\
\hline $\mathrm{O}_{2}$ & 3.83 & $\mathrm{Cu}$ & bal. \\
\hline $\mathrm{Al}$ & bal. & & \\
\hline
\end{tabular}

\subsection{Compaction process}

The die, lower and upper punches were lubricated using zinc stearate powder to decrease the friction between the die walls and the powder, and then the lower punch was assembled with the die. After that the (Cu. powder) was stacked in the steel die cavity and then the (Al. powder) was stacked.

The full specimen powders (bimetal powder) inside the die were uniaxially cold compacted by slowly increasing pressure up $350 \mathrm{MPa}$ which (equal to machine load of 12 ton) at a compression testing machine capacity of 500 ton capacity produced by (werkstoff pruf maschinen WPM Germany).

\subsection{Sintering process}

After the compaction process, the green compacted specimens were sintered at various sintering temperature under flow of Ar gas in the horizontal tube furnace (model MTI XD1400MT). The powder sintering temperature varies from

(0.7 to 0.9$)$ of the melting point [26]. Because of the difference in melting temperature between the $\mathrm{Cu}\left(1083^{\circ} \mathrm{C}\right)$ and $\mathrm{Al}\left(660^{\circ} \mathrm{C}\right)$, different sintering temperatures were applied, 300,500 and $600^{\circ} \mathrm{C}$. In certain conditions the sintering temperature is normally under the melting temperature of all powder. Thus, the sintering temperature should be under the melting temperature of aluminum. The holding sintering time was set at $2 \mathrm{~h}$.

\subsection{Structural evaluation}

Three cylindrical $\mathrm{Al} / \mathrm{Cu}$ bimetallic specimens at various sintering temperatures were fabricated with $21 \mathrm{~mm}$ diameter and $6 \mathrm{~mm}$ thickness approximately. Specimens for microstructure inspection were cut with a diamond saw perpendicular to layer surface, and their surfaces were ground, polished carefully and subsequent etching with a keller's etch ( $1.5 \mathrm{ml}$ hydrochloric acid, $1.0 \mathrm{ml} 40 \%$ hydrofluoric acid, $2.5 \mathrm{ml}$ nitric acid, $95 \mathrm{ml} \mathrm{H}_{2} \mathrm{O}$ ) and then the microstructure features were characterized by (SEM) with (EDS) analysis using (JEDL- JSM 5400LV) microscope. EDS techniques are applied to obtain the intermetallic compounds chemical composition.

$\mathrm{X}$-ray diffraction (XRD) analysis was conducted to appear the phase composition. The data was collected at room temperature with a $2 \theta$ range between $30^{\circ}$ and $90^{\circ}$ with a step size and scan rate of $0.03^{\circ}$ and $6 \mathrm{~s}$, respectively. The X-ray tube was run at $40 \mathrm{kV}$ and 40 $\mathrm{mA}$. The XRD data was analyzed by the Williamson-Hall formula. 


\subsection{Mechanical and electrical properties}

The strength of the $\mathrm{Al} / \mathrm{Cu}$ bimetal plates bonding was measured using (Diametrical Compression Test) according to ASTM - D 3967) [27], and calculated by Eq. (1). Compression samples were machined as in Fig. 3.

$$
\sigma_{\mathrm{t}}=\frac{2 F}{\pi h d}
$$

Where $\sigma_{t}$ is fracture strength (MPa), F is applied force $(\mathrm{N}), \mathrm{h}$ is specimen height $(\mathrm{mm})$, and $\mathrm{d}$ is specimen diameter $(\mathrm{mm})$.

Vickers microhardness (Leitz Durimet) for the $\mathrm{Al} / \mathrm{Cu}$ bimetallic plate across the bonded interface was carried out at $50 \mathrm{~g}$ load for a testing time of $10 \mathrm{~s}$.

Digital Low Resistance Ohmmeter (DLRO 10X) as appeared in Fig. 4 was used in fourpoints technique for measuring the electrical resistivity of the specimens by applying at (10 amp.) between the specimens ends [28, 29]. The Eq. (2) stated below was applied to calculate resistivity.

$$
\rho=\frac{R \times A}{L}
$$

Where $\rho$ is resistivity ( $\mu \Omega \cdot \mathrm{mm}), \mathrm{R}$ is resistance $(\mu \Omega)$, A is contact area $\left(\mathrm{mm}^{2}\right)$, and $\mathrm{L}$ is distance of potential probes $(\mathrm{mm})$

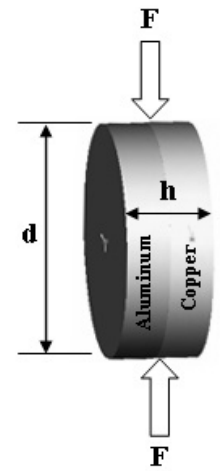

Fig. 3. Diametrical compression test specimen

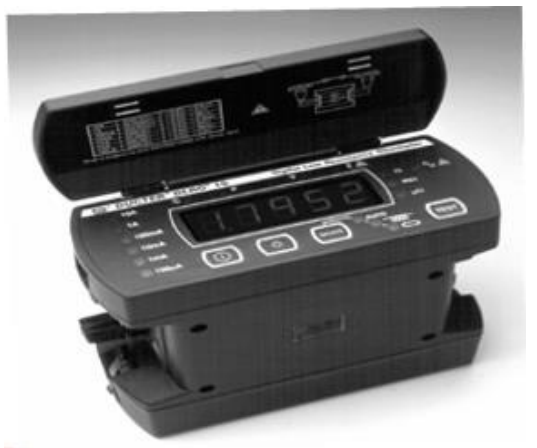

Fig. 4. Digital low resistance ohmmeter (DLRO 10X) 


\subsection{Physical properties}

Volume shrinkage percentage (V.Sh)\% and porosity percentage (P)\% were obtained. Volume shrinkage percentage was obtained using Eq. (3) and the porosity percentage was determined based on the Archimedes' theory using Eq. (4).

$$
\text { Percent of volume shrinkage (V.Sh) } \%=\frac{V_{0}-V_{f}}{V_{0}} \times 100
$$

Where $V_{o}$ is volume before sintering $\left(\mathrm{mm}^{3}\right)$, and $V_{f}$ is volume after sintering $\left(\mathrm{mm}^{3}\right)$.

$$
\text { Porosity (P) } \%=\frac{W_{s}-W_{d}}{W_{s}-W_{i}} \times 100
$$

Where $\mathrm{W}_{\mathrm{s}}$ is weight of sample in air after submerged from water and cleaned the surfaces $(\mathrm{gm}), W_{d}$ is weight of dry sample $(\mathrm{gm})$, and $W_{i}$ is weight of sample in water (gm).

\section{Results and discussion}

Three cylindrical $\mathrm{Al} / \mathrm{Cu}$ bimetal specimens at various temperatures 300,500 , and $600^{\circ} \mathrm{C}$ were produced of $21 \mathrm{~mm}$ diameter and $6 \mathrm{~mm}$ height approximately. At constant pressure, the temperature is the major controlling mechanism for bonding the two dissimilar powders $(\mathrm{Al}$ and $\mathrm{Cu})$. For microstructure and microhardness inspection the samples were sliced with a diamond saw, and their surfaces were ground, polished carefully and examined. Microstructural features were characterized by (SEM) with (EDS) analysis.

\subsection{Structural evaluation}

High magnification scanning electron microscopy, SEM, with EDS analysis using (JEDLJSM 5400LV) electron microscope was performed for each layer and inbetween the four specimens $\mathrm{Al} / \mathrm{Cu}$ bimetal. Fig. 5 shows SEM for each layer $\mathrm{Cu}$. and $\mathrm{Al}$. for all specimens after sintering at different temperatures. Figures 5 (a), 5(c), 5(e), 5(b), 5(d) and 5(f) show the SEM for $\mathrm{Cu}$. and $\mathrm{Al}$. layers respectively at various sintering temperatures 300,500 , and $600^{\circ} \mathrm{C}$. As the sintering temperature increases, porosity decreases. This due to, the formation mechanism of bonds between the particles during sintering occurs, and the number of particle-particle bond increase. This leads to diffusion mechanism occurs as the increases in temperature.

Scanning electron microscopic (SEM) with (EDS) analysis for $\mathrm{Al}, \mathrm{Cu}$ layers and inbetween them are shown in Fig. 6 and Fig. 7 for all specimens at various sintering temperatures. As the sintering temperature increase, the interface continues to develop different microstructure with gray colures.

For sample at temperature $300^{\circ} \mathrm{C}$, an intermetallic compounds IMCs were developed beside the $\mathrm{Al}$ layer as noticed in Fig. 6(a). The compound with Al-rich (marker EDS3) was observed.

As the increasing of the temperature to $500^{\circ} \mathrm{C}$, the IMCs continue to thicken and a visible two IMCs noticed in Fig. 6(b) with markers (EDS3 and EDS4). When the temperature reaches $600^{\circ} \mathrm{C}$, the IMCs continues to grow and three IMCs were formed with markers EDS3, EDS4, and EDS5 as observed in Fig. 6(c).

The different IMCs were identified, and the EDS analysis results in Table 4 identify these structures (EDS1 to EDS5) as $\mathrm{Al}, \mathrm{Al}_{2} \mathrm{Cu}, \mathrm{Al}_{4} \mathrm{Cu}_{9}, \mathrm{AlCu}$, and $\mathrm{Cu}$ respectively. The phases formed here are consistent with those presented in the interfacial zone of the $\mathrm{Cu} / \mathrm{Al}$ couple casting [30, 
Moataz H. Ata, Properties of Al/Cu bimetallic plate prepared by P/M technique: Sintering ...

31]. According to the binary phase diagram of the Al-Cu system as observed in Fig. 1, it can be seen that several $\mathrm{Al}-\mathrm{Cu}$ phases are stable at the studied temperature from $300-500^{\circ} \mathrm{C}$.

Figure 8 shows the $\mathrm{X}$-ray diffract graphs (XRD) of $\mathrm{Al} / \mathrm{Cu}$ bimetallic specimens for different sintering temperatures. At the temperature of $300^{\circ} \mathrm{C}$, the (IMC) of $\mathrm{Al}_{2} \mathrm{Cu}$ were detected. At the sintering temperatures 500 and $600^{\circ} \mathrm{C}$, the $\mathrm{IMCs}$ of $\mathrm{Al}_{4} \mathrm{Cu}_{9}$ and $\mathrm{AlCu}$ are formed respectively and $\mathrm{Al} / \mathrm{Cu}$ bimetal fall off during crack propagation between $\mathrm{Al}$ and $\mathrm{Cu}$ layers as in Fig. 6(c) which attributed to the increase of the amount high brittle IMCs as $\mathrm{Al}_{4} \mathrm{Cu}_{9}$ and $\mathrm{AlCu}$. According to previous study [32], the formation energies of $\mathrm{Al}_{4} \mathrm{Cu}_{9}$ and $\mathrm{Al}_{2} \mathrm{Cu}$ are $0.83 \mathrm{eV}$ and $0.78 \mathrm{eV}$, and there is a greater diffusivity of $\mathrm{Cu}$ in $\mathrm{Al}$ than that of $\mathrm{Al}$ in $\mathrm{Cu}$. Thus the first reaction product $\mathrm{Al}_{2} \mathrm{Cu}$ is presumed then the next reaction phase is $\mathrm{Al}_{4} \mathrm{Cu}_{9}$. $\mathrm{AlCu}$ is next. The same results could be observed in this study.
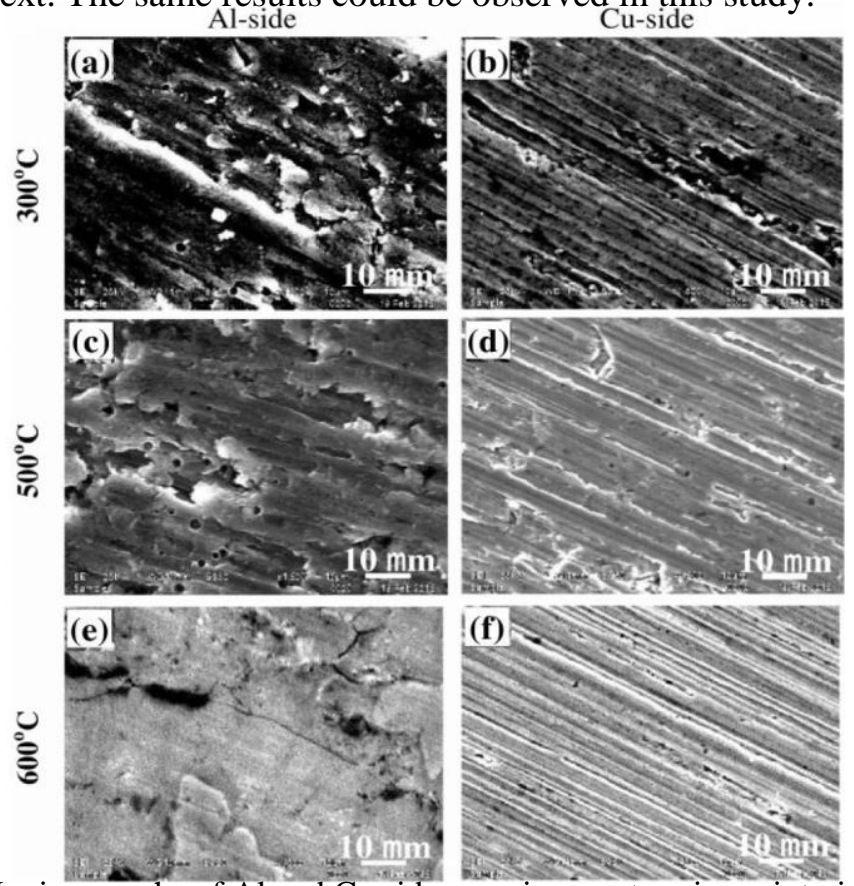

Fig. 5. SEM micrographs of $\mathrm{Al}$ and $\mathrm{Cu}$ sides specimens at various sintering temperatures
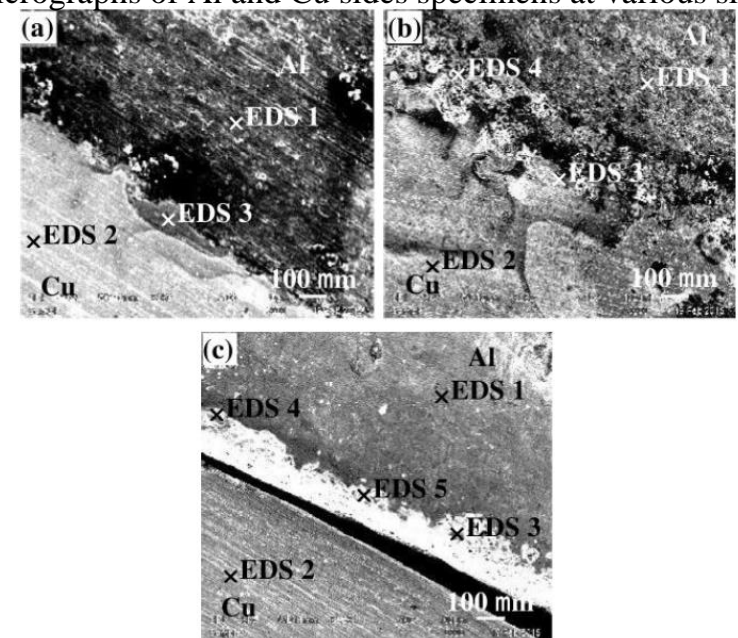

Fig. 6. Interface development for $\mathrm{Al} / \mathrm{Cu}$ bimetal under various sintering temperatures, (a) $300^{\circ} \mathrm{C}$, (b) $500^{\circ} \mathrm{C}$, and (c) $600^{\circ} \mathrm{C}$. 
Table 4.

EDS analysis results of specimens pointed in Fig. 6.

\begin{tabular}{|c|c|c|c|}
\hline Marker & $\mathrm{Al}($ at. \%) & $\mathrm{Cu}$ (at. \%) & Possible phases \\
\hline EDS 1 & 99 & 1 & $\mathrm{Al}$ \\
\hline EDS 2 & 0 & 100 & $\mathrm{Cu}$ \\
\hline EDS 3 & 67.7 & 32.3 & $\square \square \square \mathrm{Al}_{2} \mathrm{Cu}$ \\
\hline EDS 4 & 43.8 & 56.2 & $\square_{\square} \square \square \mathrm{Al}_{4} \mathrm{Cu}_{9}$ \\
\hline EDS 5 & 48.8 & 51.2 & $\square_{\square} \square \square \mathrm{AlCu}$ \\
\hline
\end{tabular}
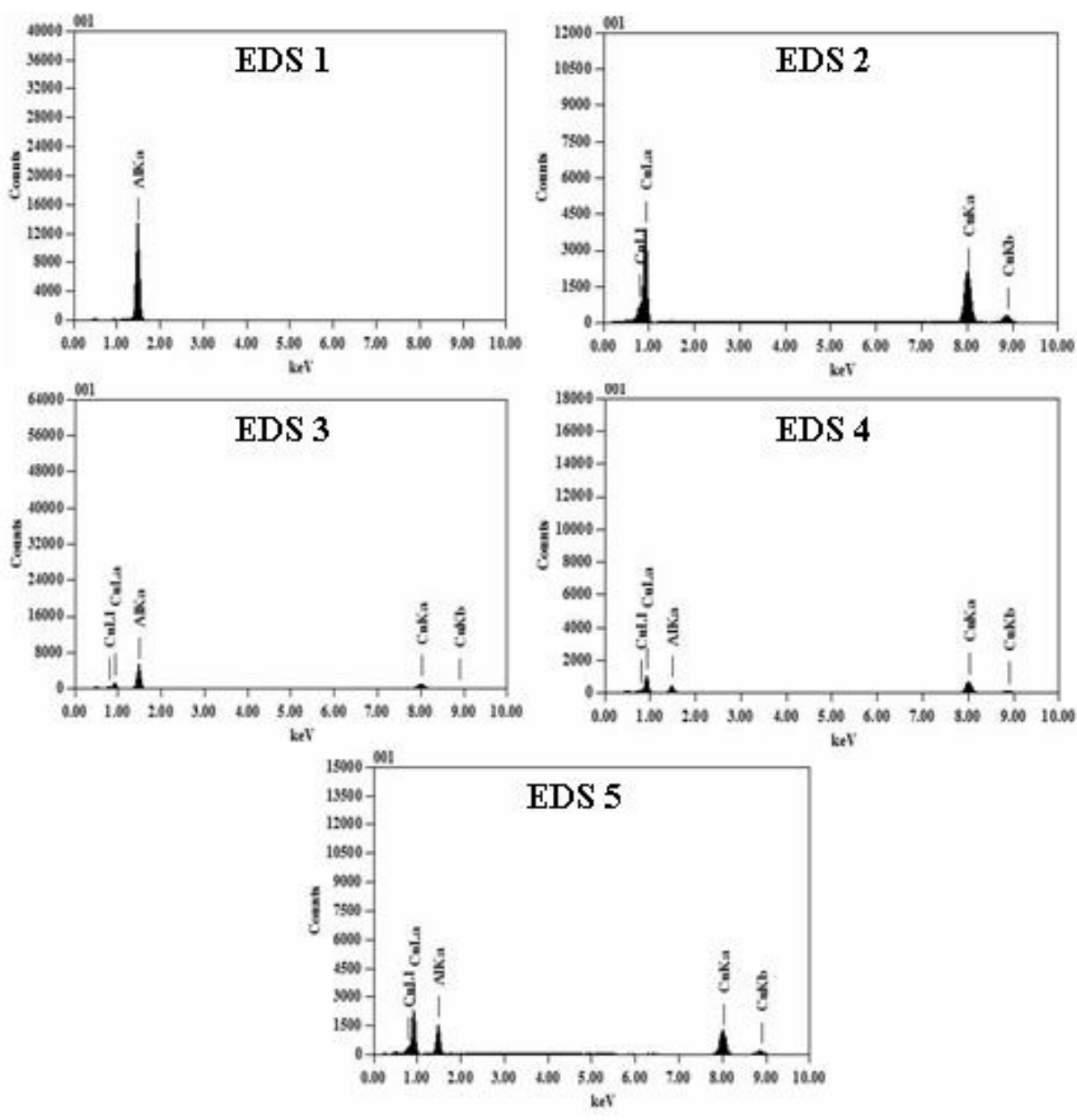

Fig. 7. EDS spectra for the different markers 


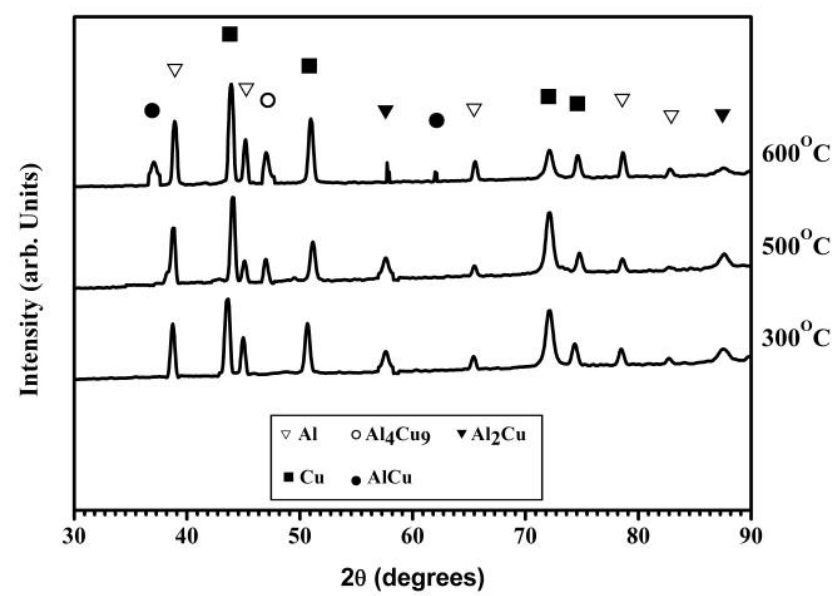

Fig. 8. X-ray diffraction patterns measured on the $\mathrm{Al} / \mathrm{Cu}$ bimetal specimens at various sintering temperatures

\subsection{Shrinkage measurement}

Volume shrinkage percentage (V.Sh)\% was measured for aluminum, copper and $\mathrm{Al} / \mathrm{Cu}$ bimetal separately using Eq. (3). Figure 9 appear the (V.Sh)\% with the various sintering temperature. For $\mathrm{Cu}$. and $\mathrm{Al}$. plates, It can be noticed that as the sintering temperature increase, the (V.Sh)\% increases. As the sintering temperature increases, the difference of (V.Sh)\% between $\mathrm{Cu}$. and $\mathrm{Al}$. decreases to reach the minimum value of (V.Sh)\% at sintering temperature $500^{\circ} \mathrm{C}$. Rabin et al. [33] noticed that, as the difference of (V.Sh)\% between the two layer decreases, the stresses concentration decreases and eliminate the crack formation.

For $\mathrm{Al} / \mathrm{Cu}$ bimetal, it is appeared that, as the sintering temperature increase from 300 to $500^{\circ} \mathrm{C}$, the (V.Sh) $\%$ increases from $(3.76 \%)$ to $(11.31 \%)$, this increase occurs because the particles converge increases. However, at the sintering temperature $600^{\circ} \mathrm{C}$ the (V.Sh)\% decreases to $(7.87 \%)$ this occurs as a result of two reasons (1) increase brittle IMCs amounts and (2) crack formation between $\mathrm{Al}$ and $\mathrm{Cu}$ layers as in Fig. (6c).

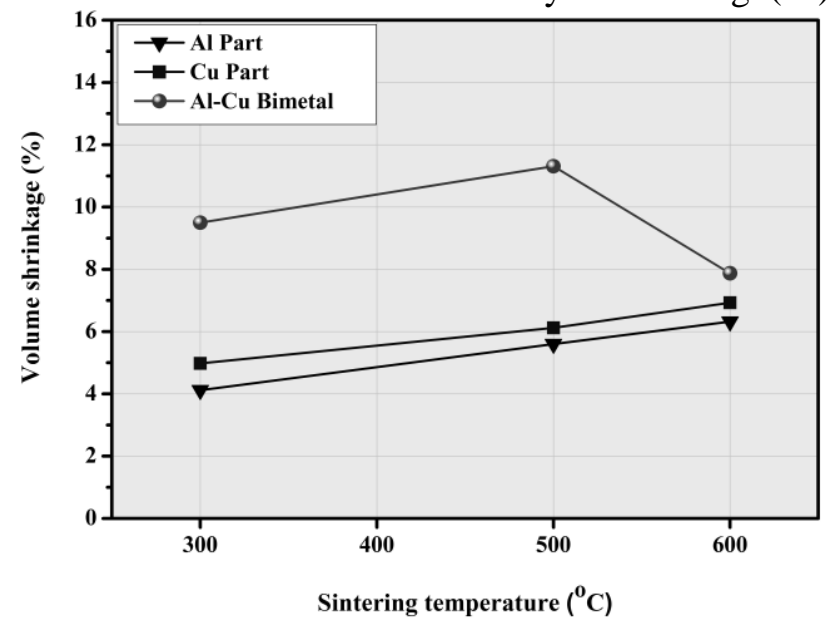

Fig. 9. Shrinkage percentages of the $\mathrm{Al}$ plate, $\mathrm{Cu}$ plate and $\mathrm{Al} / \mathrm{Cu}$ bimetal at various sintering temperatures 


\subsection{Porosity measurement}

Porosity percentage (P)\% was obtained by Eq. (4). Figure 10 explains that, as the sintering temperature increases from 300 to $500^{\circ} \mathrm{C}$, porosity decreases related to increase of the liquidus phase amount formation which leads to close the pores. But at $600^{\circ} \mathrm{C}$, the (P)\% decreases. This decrease is related to the formation of more hard and brittle IMCs. The lowest $(\mathrm{P}) \%$ was obtained the $\mathrm{Al} / \mathrm{Cu}$ bimetal at sintering temperature $500^{\circ} \mathrm{C}$.

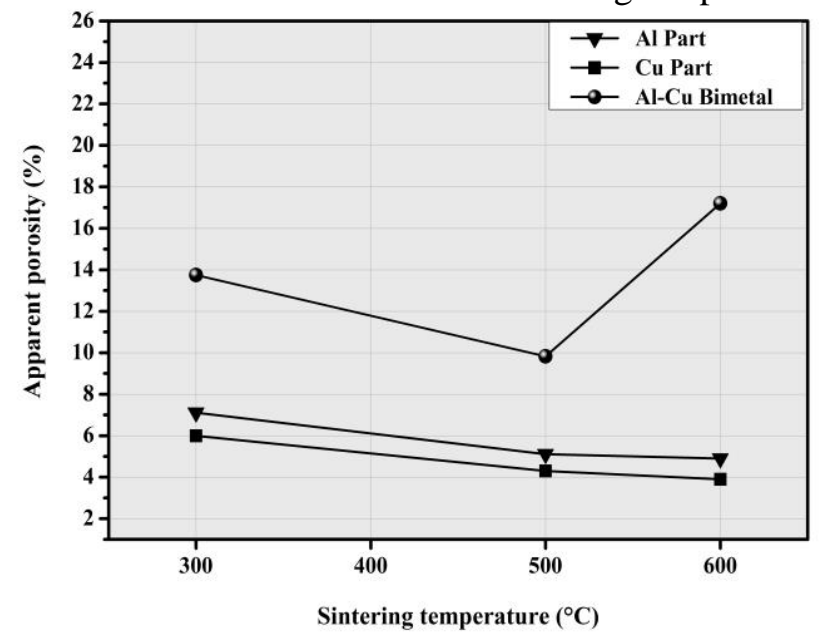

Fig. 10. Porosity percentages of the $\mathrm{Al}$ plate, $\mathrm{Cu}$ plate and $\mathrm{Al} / \mathrm{Cu}$ bimetal at various sintering temperatures

\subsection{Bonding strength}

The strength of the $\mathrm{Al} / \mathrm{Cu}$ bimetal bonding was measured using (Diametrical Compression Test) and calculated by Eq. (1). The result analysis show that the decrease of bond strength is not directly proportional to the intermetallic width, which reveals that there are some other mechanisms affect on the strength of bonding of these material during sintering process.

The strength of the samples bonding processed at various sintering temperatures is obtained in Fig. 11. For the sample at $300^{\circ} \mathrm{C}$, the poor strength is due to low sintering temperature, which lead to not diffusion occurs and low particle bonds. For the sample at $600^{\circ} \mathrm{C}$, minimum compression strength of $342 \mathrm{MPa}$ was obtained. The poor strength exhibited by this sample is attributed to the foundation of different and growth of hard and brittle IMCs and poor contact between $\mathrm{Al}$ and $\mathrm{Cu}$ layers due to crack propagation at the interface. The observations indicate that good bonding strength was exhibited by the samples processed at $300^{\circ} \mathrm{C}$ and $500^{\circ} \mathrm{C}$ with increasing the sintering temperatures. Maximum bonding strength was obtained by the sample which sintered at $500^{\circ} \mathrm{C}$. This is due to the lower porosity as in Fig. 10 and optimum sintering temperature $\left(500^{\circ} \mathrm{C}\right)$, which lead to good diffusion and particle bond occurred. 


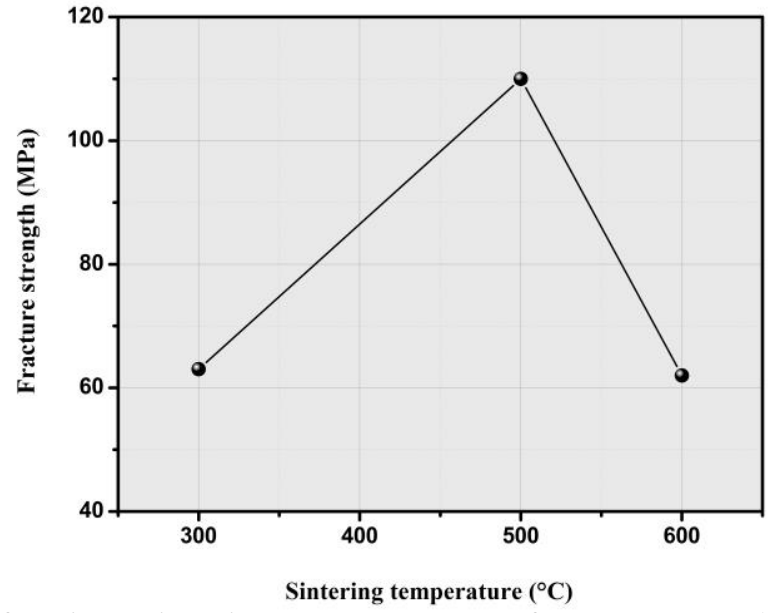

Fig. 11. Effect of various sintering temperature on fracture strength of $\mathrm{Al} / \mathrm{Cu}$ bimetal

\subsection{Microhardness}

Figure 12 shows hardness value (HV) of different intermetallics for $\mathrm{Cu} / \mathrm{Al}$ bimetal at various sintering temperatures. The influence of the IMCs at the $\mathrm{Cu} / \mathrm{Al}$ bimetal was investigated. It is observed that the higher hardness at the interface than on the base metals, due to produce a different IMCs inbetween $\mathrm{Cu}$. and $\mathrm{Al}$.. Previous experiments as Xue et al., Reddy et al. and Feng et al. [34-37] indicated the same observation. The minimum microhardness values were recorded for the sintered sample at temperature $300^{\circ} \mathrm{C}$. As the sintering temperature increases, the hardness value increases due to decrease the porosity of $\mathrm{Cu}$. and Al. as in Fig. 10.

Hardness value of $325 \mathrm{VHN}$ was obtained for the sintered sample at $300^{\circ} \mathrm{C}$. Two

IMCs with values of 325 and $550 \mathrm{VHN}$ were noticed for the sintered sample at $500^{\circ} \mathrm{C}$.

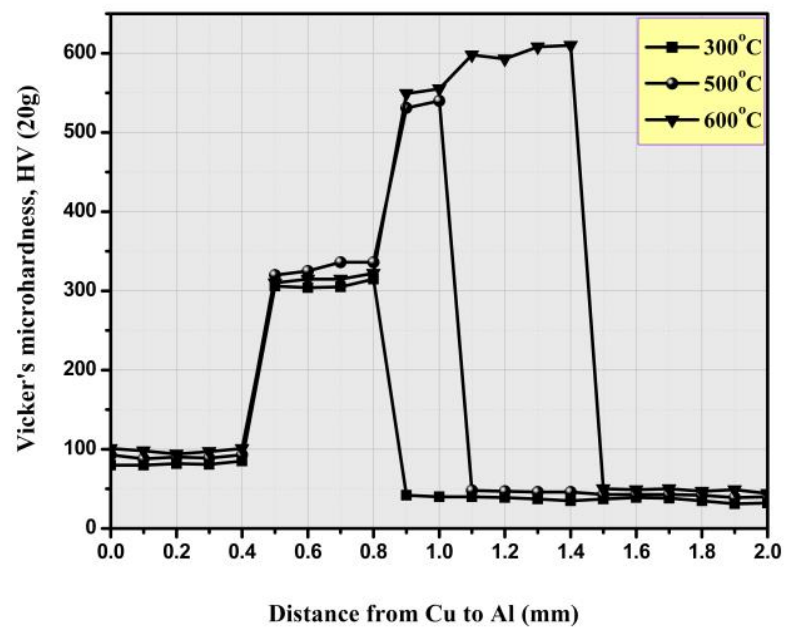

Fig. 12. Typical distribution of hardness in the $\mathrm{Cu} / \mathrm{Al}$ bimetal under various sintering temperatures

Finally, three IMCs were recorded for the sintered sample at $600^{\circ} \mathrm{C}$ with values of 325 , 550 and $620 \mathrm{VHN}$. According to Table 1, which are taken from [21,22].The hardness values of 325,550 and $620 \mathrm{VHN}$ for the IMCs refer to $\mathrm{Al}_{2} \mathrm{Cu}, \mathrm{Al}_{4} \mathrm{Cu}_{9}$ and $\mathrm{AlCu}$ respectively. $\mathrm{A}$ 
greater hardness of $\mathrm{AlCu}$ (IMC) for the sintered sample at $600^{\circ} \mathrm{C}$ lead to low mechanical integrity, thus leading to the brittleness and lower bonding strength of the $\mathrm{Cu} / \mathrm{Al}$ bimetal as in Fig.11, which is in good agreement with the results obtained in the previous work [38].

\subsection{Electrical resistance}

Figure 13 illustrates the effect of various sintering temperatures on the electrical resistivity for $\mathrm{Al} / \mathrm{Cu}$ bimetal. There is no effect of $\mathrm{Al}_{2} \mathrm{Cu}$ and $\mathrm{Al}_{4} \mathrm{Cu}_{9}$ IMCs phase that formed in the sintered sample at 300 and $500^{\circ} \mathrm{C}$ on the electrical resistivity, due to the growth of these IMCs with small quantities.

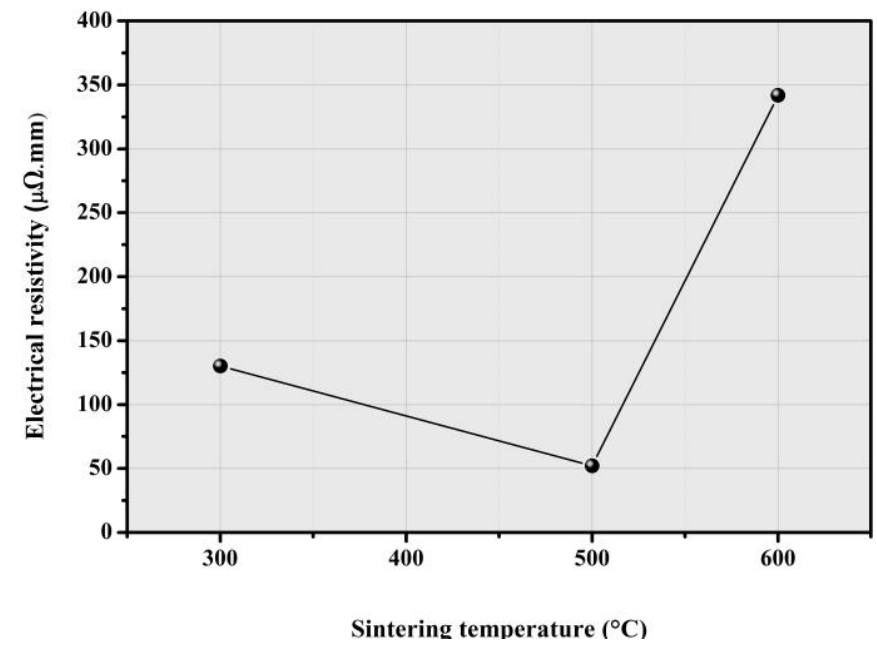

Fig. 13. Effect of various sintering temperatures on electrical resistivity of $\mathrm{Al} / \mathrm{Cu}$

The decreasing of the electrical resistivity for the sintered sample at $500^{\circ} \mathrm{C}$ is because of the good sintering temperature which lead to good diffusion and particle bond occurred. The increasing of the electrical resistivity for the sintered sample at $600^{\circ} \mathrm{C}$ is caused by increasing high brittle IMCs with high electrical resistivity as in Table 1, which is in good agreement with the results obtained by Cheng et al. [39] and Abbasi et al. [2].

\section{Conclusions}

The microstructure of $\mathrm{Al}-\mathrm{Cu}$ bimetallic plate and its interface were identified and discussed. Moreover, the relation between microstructure and several properties was investigated. The conclusions were summarized as follows:

- From the EDS and XRD analysis for the Al-Cu bimetallic plates. It was appeared that, as the sintering temperature increased, the first reaction product $\mathrm{Al}_{2} \mathrm{Cu}$ was presumed, and then the next reaction phase is $\mathrm{Al}_{4} \mathrm{Cu}_{9}$ and $\mathrm{AlCu}$ is next.

- As the sintering temperature increased from 300 to $500^{\circ} \mathrm{C}$, the volume shrinkage percentage increased due to the particles converges increased. However, at $600^{\circ} \mathrm{C}$ the volume shrinkage percentage decreases due to two the increase of brittle IMCs amounts.

- Bonding strength of $\mathrm{Al}-\mathrm{Cu}$ bimetallic plates were increased to maximum value the sintered sample at $500^{\circ} \mathrm{C}$ and then decreased at $600^{\circ} \mathrm{C}$.

- There is no effect of $\mathrm{Al}_{2} \mathrm{Cu}$ and $\mathrm{Al}_{4} \mathrm{Cu}_{9}$ IMCs phase that formed in the sintered sample at 300 and $500^{\circ} \mathrm{C}$ on the electrical resistivity, due to the formation of these IMCs with small quantities. 
Moataz H. Ata, Properties of Al/Cu bimetallic plate prepared by P/M technique: Sintering ...

\section{REFERENCES}

[1] Ouyang, J., Yarrapareddy, E., and Kovacevic, R., 2006, "Microstructural Evolution in The Friction Stir Welded 6061 Aluminum alloy (T6-Temper Condition) to Copper," Mater. Process. Technol., 172(1), pp. 110-112.

[2] Abbasi, M., Taherib, A. K., and Salehi, M. T., 2001, "Growth Rate of Intermetallic Compounds in $\mathrm{Al} / \mathrm{Cu}$ Bimetal Produced by Cold Roll Welding Process," Alloys Compd., 319(1-2), pp. 233-241.

[3] Mai, T. and Spowage, A. C., 2004, "Characterisation of Dissimilar Joints in Laser Welding of Steel-Kovar, Copper-Steel and Copper-Aluminium," Mater. Sci. Eng. A., 374(1-2), pp. 224-233.

[4] Lee, W. B., S. Bangk, and Jung S. B., 2005, "Effects of Intermetallic Compound on the Electrical and Mechanical Properties of Friction Welded Cu/Al Bimetallic Joints During Annealing," Alloys Compd., 390(1-2), pp. 212-219.

[5] Sahin, M., 2010, "Joining of Aluminium and Copper Materials with Friction Welding," Adv. Manuf. Techno., 49(5-8), pp. 527-534.

[6] Tricarico, L., Spina, R., Sorgente, D., and Brandizzi, M., 2009, "Effects of Heat Treatments on Mechanical Properties of Fe/Al Explosion-Welded Structural Transition Joints," Mater. Des., 30, pp. 2693-2700.

[7] Solchenbach, T. and Plapper, P., 2013, "Mechanical Characteristics of Laser Braze-Welded Aluminium-Copper Connections," Opt. Laser Technol., 54, pp. 249-256.

[8] Ji, F., Xue, S., and Dai, W., 2012, "Reliability Studies Of Cu/Al Joints Brazed With Zn-AlCe Filler Metals," Mater. Des., 42, pp. 156-63.

[9] Honarpisheh, M., Asemabadi, M., and Sedighim, M., 2012, "Investigation of Annealing Treatment on the Interfacial Properties of Explosive-Welded Al/Cu/Al Multilayer," Mater. Des., 37, pp. 122-127.

[10] Sedighi, M. and Honarpisheh, M., 2012, "Experimental Study of Through-Depth Residual Stress in Explosive Welded Al-Cu-Al Multilayer," Mater. Des., 37, pp. 577-581.

[11] Tan, C. W. and Jiang, A., 2013, "Microstructural Evolution and Mechanical Properties of Dissimilar Al-Cu Joints Produced by Friction Stir Welding," Mater. Des., 51, pp. 466-473.

[12] Lee, J. B., Kim, Y. H., and Jeong, H. G. 2014, "Fabrication of Micro- Sized Al/ Cu Clad by Repeated Hydrostatic Extrusion and Its Mechanical Properties," Mater. Manuf. Process.,29, pp. $683-686$.

[13] Ghadimi, S., Sedighi, M., Djavanroodi, F., and Asgari, A., 2015, "Experimental and Numerical Investigation on the Cu-Al Bimetallic Tube Prepared by ECAP.," Mater. Manuf. Process., 30, pp. 1256- 1261.

[14] Eslami, P., Karimi, A., and Zebardast, M., 2013, "A comparison Between Cold-Welded and Diffusion-Bonded Al/Cu Bimetallic Rods Produced by ECAE Process," J. Mater. Eng.

Perform., 22, pp. 3014-3023.

[15] Tao, S., Jin, L., Xiang, G., and Lei, L., 2013, "Tensile Anisotropy of Cu/Al Clad Metals After Prestrain Using Digital Image Correlation," J. Mater. Eng. Perform., 22, pp. 38253833.

[16] Kwang, S., and Yong, K., 2013, "Solid-State Bonding between Al and Cu by Vacuum Hot Pressing," Trans. Nonferrous Met. Soc. China, 23, pp. 341-346.

[17] ASM Handbooks, Vol. 3, 2002, "Alloy Phase Diagrams, ASM International," Materials Park, Ohio,

[18] Hyoung, K., Yeon, L., Wook, P., and Kwang, K., 2003, "Effect of Cu/Al Intermetallic Compound (Imc) on Copper Wire and Aluminum Pad Bondability," IEEE Trans. Compon. Packag. Manuf. Technol., 26, pp. 367-374.

[19] jie, G., LIU, G., JIN, H., and Zhong, S., 2011, "Intermetallic Phase Formation in DiffusionBonded Cu/Al Laminates," Mater. Sci., 46, pp. 2467-2473.

[20] Yuan, C. and Weng, H., 2007, "Effect of Annealing on The Interfacial Structure of Aluminum-Copper Joints," Mater. Trans., 48(1), pp. 1938-1947. 
[21] Pfeifer, S., Grossmann, S., Freudenberger, R., and Willing, H., 2012, "Characterization of Intermetallic Compounds in Al-Cu-Bimetallic Interfaces," IEEE 58th Holm Conference on Electrical Contacts Portland, pp. 1-6.

[22] Wulff, F. W., C. Breach, D., Stephan, D., and Dittmer, K. J.,2004, "Characterisation of Intermetallic Growth in Copper and Gold Ball Bonds on Aluminium Metallization," Proc. 6th Electron Packaging Technology Conference Singapore, pp.348-53.

[23] Watanabe, R. and Kawaski, A., 1987, "Powder Metallurgical Fabrication of the Thermal Stress Relief Type of Functionally Gradient Materials," In Sintering, Tokyo, 2(1), pp. 1197 1202.

[24] Schubert, T., Weibgarber, Kieback, T., B., Balzer, H., Neubing, H. C., and Baum U., 2005, "Aluminum P/M Is A challenge That Industry Can Overcome," Metal Powder Report, 60(2), pp. 32-37.

[25] Nemat-Alla, M., Ata, M., Bayoumi, M., and Khair-Eldeen, W., 2011, "Powder Metallurgical Fabrication and Microstructural Investigations of Aluminum/Steel Functionally Graded Material," Mater. Sci. Appl., 2(3), pp. 1708-1718.

[26] P.C. Sharma., 1993, "Production Engineering “, S. Chand \& Company Ltd.

[27] Geaad, F., Elttany, M., and Gaber, H., 2010, " Preparation and Studying Some Physical and Mechanical Properties of Porcelain with Using Feldspar Replacement," Iraqi J. of Mech. and Mat. Eng., 10(3), pp. 464-478.

[28] Stabik, J., and Dybowska, A., 2008, "Electrical and Tribological Properties of Gradient Epoxy-Graphite Composites," Achiev. in Mater. and Manuf. Eng., 27(1-2), pp. 39-42.

[29] Stabik, J., and Szczpanik, M., 2010, "Electrical Properties of Polymeric Gradient Materials Based on Epoxy Resin Filled With Hard Coal," Achiev. in Mater. and Manuf. Eng., 38, pp. 56-63.

[30] Zare, G. R., Divandari, M., and Arabi H., 2013, "Investigation on Interface of Al/Cu Couples in Compound Casting," Mater. Sci. Technol., 2013, 29, pp. 190.

[31] Yan, Ben, H., L., Yao, J., and Feng, S., 2015, "Investigation on The Interface of Cu/Al Couples During Isothermal Heating," Miner. Metall. Mater, 22(1-2), pp. 309.

[32] Chen, Y., Long, H., and Hwang, W., 2006, "Influence of Interfacial Structure Development on The Fracture Mechanism and Bond Strength Of Aluminum/Copper Bimetal Plate, Mater. Trans., 47, pp. 1232-1239.

[33] Rabin, B. H. and Heaps, R. J., 1993, "Powder Processing of Ni- $\mathrm{Al}_{2} \mathrm{O}_{3}$ FGM," Ceramic Trans. FGM, 34(2), pp. 173-180.

[34] Xue, P., Xiao, B., and Wang, D., 2011, "Achieving High Property Friction Stir Welded Aluminum/Copper Lap Joint At Low Heat Input," Sci. Technol. Weld. Join, 16, pp. 657-661.

[35] Muralimohan, C. Haribabu, H., S., and Reddy, H., 2014, "Evaluation of Microstructures and Mechanical Properties of Dissimilar Materials by Friction Welding," Procedia Mater. Sci., 5(2), pp. 1107-1113.

[36] Feng, J., Xue, S., and Wang, G., 2012, "Microstructure and Properties of Cu/Al Joints Brazed With Zn-Al Filler Metals," Trans. Nonferrous. Met. Soc. China, 22, pp. 281-287.

[37] Hoseini-Athar, M. M. and Tolaminejad, B., 2016, "Interface Morphology and Mechanical Properties of Al-Cu-Al Laminated Composites Fabricated by Explosive Welding and Subsequent Rolling Process," Met. Mater. Int., 22, pp. 670 680.

[38] Braunovic, M. and Alexandrov, N., 1994, "Intermetallic Compounds at Aluminum-ToCopper Electrical Interfaces: Effect of Temperature and Electric Current," IEEE Trans. Compon. Packag. Manuf. Technol., 17(1), pp. 78-85.

[39] Cheng. X., Bai. B., and Feng. C., 2009, "Microstructural Characterization of the $\mathrm{Al} / \mathrm{Cu} / \mathrm{Steel}$ Diffusion Bonded Joint," J. Rare Metals, 28(5), pp. 478-481. 
Moataz H. Ata, Properties of Al/Cu bimetallic plate prepared by P/M technique: Sintering ...

\section{خصائص ثنائى المعدن (المونيوم / نحاس) المصنعة

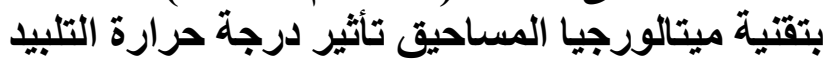

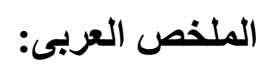

الهدف من هذا العمل هو تصنيع ثنائى المعدن من الألمونيوم/نحاس بتقنية ميتالورجيا المساحيق عند

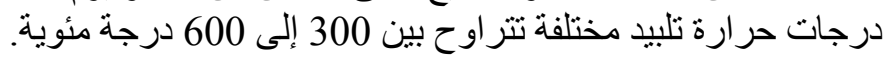

تم در اسة تأثثر درجة حر ارة التلبيد المختلفة على البنية المجهرية و الخصائص لعينات ثنائى المعدن

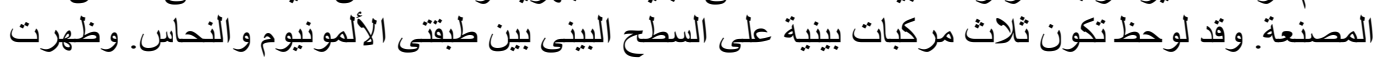

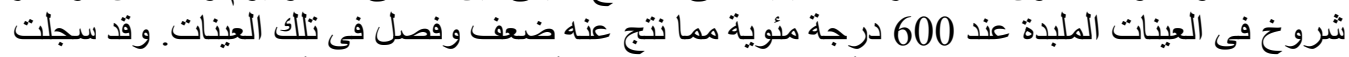

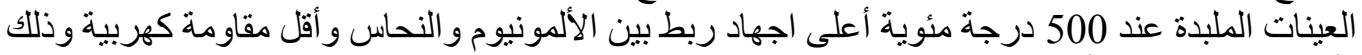

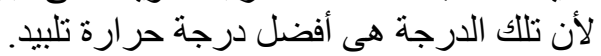

